\title{
Supplier capacity and key account management performance: a stochastic frontier analysis
}

\section{Capacidad del proveedor y desempeño de la administración de cuentas clave: análisis estocástico de frontera}

\author{
Kawsar Ahmmed ${ }^{1}$ \\ Md Azizul BateN ${ }^{2}$ \\ Md Kamrul Hossain ${ }^{3}$ \\ Nor AzIla Mohd NoOR ${ }^{4}$ \\ United International University (Bangladesh) \\ Shah Jalal University of Science and Technology (Bangladesh) \\ Daffodil International University (Bangladesh) \\ University Utara Malaysia (Malaysia)
}

Recibido el 30 de marzo de 2016, aceptado el 20 de diciembre de 2016

Publicado online el 19 de julio de 2017

$\mathrm{N}^{\mathrm{o}}$ de clasificación JEL: M3, M310

DOI: $10.5295 / \mathrm{cdg} .160642 \mathrm{ka}$

\begin{abstract}
:
Taking the influences of operational, organizational and relational factors on key account management performance into account, present research examines the antecedent variables of key account management performance. Using a questionnaire, data from 112 ready-made garments companies in Bangladesh were used to evaluate Capacity Oriented Key Account Management Performance through Stochastic Frontier Model. Results show that in the case of medium key account serving capacity, log-likelihood estimation of Maximum Likelihood Estimation (MLE) is found same as the Ordinary Least Square (OLS) estimation whereas for both high and low key account serving capacity, MLE is found better than OLS estimation. It is observed that perceived risks of serving key account, supplier relational investment, and relational intimacy are significant in case of both MLE and OLS estimation methods while in case of MLE team effort and supplier relational investment are recorded significant for the high, medium and low key account serving capacity oriented performance of Banglades-
\end{abstract}

\footnotetext{
${ }^{1}$ School of Business and Economics, House \# 80, Road \# 8/A, Dhanmondi R/A, Dhaka-1209, Bangladesh. kahmed. ba@gmail.com

${ }^{2}$ Department of Statistics, School of Physical Sciences, Sylhet-3114, Bangladesh. baten_math@yahoo.com

${ }^{3}$ Department of Natural Sciences, Faculty of Science and Information Technology, Dhaka - 1207, Bangladesh, kamrul.ns@diu.edu.bd

${ }^{4}$ Othman Yeop Abdullah Graduate School of Business, 06010 Sintok, Kedah Darul Aman, Malaysia. azila@uum. edu.my
} 
hi ready-made garments companies. Again, most of the companies with high key account serving capacity are found showing above average performance, the performance of the companies with medium key account serving capacity is homogeneous. On the other hand, the performance of low key account serving capacity garments companies are more volatile than garments companies with medium and high key account serving capacity. Implications, limitations, and further research options are suggested.

\section{Keywords:}

Key account management performance, stochastic frontier analysis, ready-made garments industry, Bangladesh.

\section{Resumen:}

Teniendo en cuenta la influencia de los factores operativos, organizativos y relacionales sobre el rendimiento de la gestión de grandes cuentas; la presente investigación examina las variables antecedentes del rendimiento de grandes cuentas. Tomando como base los resultados de una encuesta entre 112 empresas de Bangladesh dedicadas a la confección de prendas de vestir, se evalúa el desempeño de la gestión de grandes cuentas orientada a la capacidad a través del modelo de frontera estocástico. Los resultados muestran que en el caso de grandes cuentas con capacidad media de entrega, la estimación de máxima verosimilitud (MLE) vía logaritmo de la verosimilitud es igual que la estimación de mínimos cuadrados ordinarios (OLS). Para grandes cuentas con capacidades de entrega altas o bajas, la estimación de MLE es mejor que la estimación de OLS. Se observa que los riesgos percibidos de entrega a grandes cuentas, la inversión relacional de los proveedores y la intimidad relacional son significativos en el caso de los métodos de estimación MLE y OLS; mientras que en el caso de MLE el esfuerzo del equipo y la inversión relacional de los proveedores se muestran significativos para las empresas con alta, media y baja capacidad. Una vez más, la mayoría de las empresas con una alta capacidad de entrega a grandes cuentas muestran un rendimiento por encima del promedio, mientras que el rendimiento de las empresas con una capacidad media es homogéneo. Por otro lado, el desempeño de las empresas de baja capacidad de entrega es más volátil que el de las empresas con capacidad media y alta. Se sugieren las implicaciones, limitaciones y las líneas futuras de investigación.

\section{Palabras clave:}

Desempeño de la gestión de grandes cuentas, análisis estocástico de fronteras, industria de confección de prendas, Bangladesh. 


\section{INTRODUCTION}

Key account management is regarded as the supplier company initiated relational approach for its most important customers to solve their complex requirements with a special treatment that ultimately ensures attainment of both parties' financial and nonfinancial objectives (Ahmmed and Noor 2012). These indicate that supplier needs to provide special treatment in the areas of marketing, administration, and service to meet the complex requirements of key accounts (Barret 1986). By combining individual skills and knowledge of its employees along with the available resources a firm can develop its marketing capabilities (Vorhies and Morgan 2005) to serve the key customers. In the buyer-seller relationship capacity implies what the parties can do for each other, the functions they will perform and the level and importance of those activities (Ford, Håkansson, and Johansan 1986). Through this capacity, firm uses its tangible and intangible resources to understand buyer complex and specific requirements (Day 1994) which eventually allows firms to produce superior performance (Ruiz-Ortega and García-Villaverde 2008).

From the context of the service industry, Lovelock (1992) relates capacity with the optimum level of output that can be generated within a period of time utilizing a given set of resources including human, equipment, and infrastructure. To this end, this study indicates the supplier capacity as its ability to serve a maximum number of key accounts per year. From the total sample of 112 suppliers in this study, 33 companies fall into the high category, 35 companies fall into the medium category, and 44 companies fall into low capacity supplier category in the garments industry in Bangladesh. Previous studies contend that capabilities are particularly firm-specific and developed within the firm (Henderson and Cockburn 1994; McGrath et al. 1995). Several empirical works have showed that key account management (KAM) capability-related constructs, like top management involvement and support, usage of team, relational intimacy or bond, relational investment and others, can enhance firm performance in the exchange relationship (Napolitano 1997; Perry et al. 1999; Buvik and John 2000; Kim et al. 2006) and may applicable in the key account-supplier relationship in the context of readymade garments industry in Bangladesh.

Readymade garments (RMG) industry in Bangladesh is acting as a leading contributor to improving its economic strength and appeared as the backbone for the economic development of the country (Rahman and Mirdha 2009). The garments industry employed about 4 million people from more than 160 million and carried their torch of aspirations and success since the beginning of this industrial sector (Rahman 2010; Bangladesh Garment Manufacturers and Exporters Association-BGMEA 2016). Bangladesh is now in the second position with an export volume of 28 billion worth of garments in the world apparel market (Breed 2012; BGMEA 2016). The country's overseas sales of apparels grew by 10.21 percent of the fiscal year 2015-2016 compared to the fiscal year 2014-2015 (BGMEA 2016). Besides the success stories, today these garments manufacturers and exporters are facing numerous challenges (Haider 2007; Nuruzzaman and Haque 2009). Haider (2007) suggested that for the long-term sustainability of garments industry competitive issues needed to be addressed with special care. Rahman (2010) mentioned that the challenges for the Bangladeshi garment entrepreneurs are formidable. It is certainly a huge task for garments exporters to manage these customers and perform well necessary to be competitive (Rahman 2010). Managing the key customer's expectation with full devotion 
became a major concern for the garments industry as buyers demands are changing; the competitive situation is becoming harder than before (Huq 2006; Nuruzzaman and Haque 2009; Haque 2010; Rahman 2010).

To the best of knowledge, regardless of the importance of managing the key customers properly, the empirical study on key account management performance in the context of Bangladesh is absent and the necessity for quantitative empirical research on this topic is indubitable (Shi et al. 2010). Tsai and Chen (2008) mentioned that in the Asian context key account management literature are very rare. Researches relating to key account management were conducted in western and other developed countries like South African perspective (Abratt and Kelly 2002), perspective of United States (Boles et al. 1999), Germany context (Homburg et al. 2002; Homburg et al. 2003), context of The Netherlands (Kempeners and van der Hart 1999); from the perspective of United Kingdom (Millman and Wilson 1999); from Finland context (Ojasalo 2001), a French perspective (Pardo 1999); and from the context of Australian (Spencer 1999).

From the theoretical point of view, various studies highlighted that understanding the antecedents of key account management performance is lacking (Workman et al. 2003; Sharma 2006). Unfortunately, previous researchers do not include evaluating the key account management performance and there is very limited knowledge on what factors lead to successful or unsuccessful key account management (Sharma 2006; Zupancic 2008) and what are the impact of successful key account management strategy (Workman et al. 2003). To fill these gaps many academicians suggested further empirical investigation on this field (Abratt and Kelly 2002; Workman et al. 2003; Sharma 2006; Zupancic 2008; Guesalaga and Johnston 2010). Thus, to explore the key account management performance and its impact on the outcome performance, the ample empirical research in different area or country is necessary (Tsai and Chen 2008).

In this study, an attempt has been made to address the issue of "what are the capacity oriented factors that contribute to key account management performance in garments industry in Bangladesh". Specifically, this research attempt to evaluate the level of capacity oriented key account management performance among Bangladeshi garments companies using stochastic frontier analysis. It examines the influence of factors on the capacity oriented key account management performance in the readymade garments industry in Bangladesh.

\section{MATERIALS AND METHODS}

\subsection{Sources and data collection}

Readymade garments industry in Bangladesh was the population for the present study. The unit of analysis was garments manufacturer and merchandising manager of the respective manufacturer represented the individual garments company. Merchandising managers were chosen for several reasons including:

Firstly, merchandising manager represents garments manufacturer before the key customers in their procurement process.

Secondly, they have the real life knowledge of dealing with the big accounts. 
Thirdly, they act as boundary spanner between the firm and key accounts.

Finally, they have access to the top management regarding various issues relating to serving the customers purposes properly and at the same time ensure the organizational interest.

According to the Bangladesh Garments Manufacturers and Exporters Association (BGMEA), among the 3920 (4363 companies in 2016) garments companies, more that 2693 (3593 companies in 2016 representing 82\%) companies are located in Dhaka and in greater Dhaka district (BGMEA member list 2010 and 2016). Besides, almost all of the companies outside Dhaka city are the sister concerns of the existing companies having their factories and corporate offices in Dhaka. Due to the majority of the companies located in Dhaka city, this study considered the companies located in Dhaka city for data collection.

Following the Krejcie and Morgan's (1970) table, 336 companies are taken as the sample size for the study to administer the questionnaire. However, to ensure the minimum response rate and taking into account the fact that survey research generates poor response rate, researcher distributed 600 questionnaires to the selected garments companies. As a simple, flexible and versatile form of probability sampling technique (Cooper and Schindler 2006), this study used systematic random sampling technique that assures known and equal probability of selection of each element in the study population which makes it basically equivalent to simple random sampling technique (Black 2010).

For the present study, data were collected through survey questionnaire that was administered personally. High business pressure, the inability of the front line employees to cooperate with the researcher, prevalence of unrest situation in the industry as well as the firms' restriction for outsiders made the situation tougher to manage an appointment and collect data on the practice of key account management strategy in their organizations. Eventually, 112 finished questionnaires were returned from the 600 companies that represent an $18.70 \%$ response rate. Previous studies show various rate like $23.3 \%$ in study done in US and Germany (Homburg et al. 2002), 18.6\% in North America and Western Europe (Shi et al. 2010), 16.5\% in Germany (Wengler et al. 2006), 23.3\% in US and Germany (Workman et al. 2003), 20.8\% in Europe and North America (Zupancic and Müllner 2008). Therefore, the response rate for the present study is comparable to those of previous studies.

\subsection{Measurements of the variables}

Based on the Cronbach's Alpha reliability coefficient this study borrowed measurements from the extant literature to complete the survey. Key account management performance was measured using seven items borrowed from the study of Workman et al. (2003) with the internal reliability of 0.85 . Internal alignment was measured borrowing the scale with six items from the study of Jaworski and Kohli (1993) with an alpha value of 0.80 . Perceived risks of serving the key account were measured borrowing the scale from the study of Wuyts and Geyskens (2005) that consists of four items represents the partner opportunism risks with an alpha value of is 0.81 . Top management emphasis variable was measured using scale borrowed from the studies of Salojärvi et al. (2010) and Atanasova and Senn (2011) with an alpha value of 0.74 and 0.811 respectively. The scale of Workman 
et al. (2003) was used to measure team effort with the alpha value of 0.82 . Supplier relational investment and perceived buyer relational investment were measured with the scale adapted from the study of Ganesan (1994) with a reliability coefficient of 0.76 . Scale with an alpha value of 0.8029 from the study of Sin et al. (2002) was used to measure relational intimacy. Each item for the study variables is scored on 5 point Likert scale with anchors " $1=$ strongly disagree" to " $5=$ strongly agree". On the other hand, constructed ratio scale was used to collect data on customer serving capacity per year.

\subsection{Description of the variables}

Dependent variable

Key Account Management (KAM) Performance $(Y)$ is a firm-wide initiative where firms systematically and proactively deliver strategic solutions to multiple contacts at targeted accounts with a purpose of capturing a dominant share over time (Sherman et al. 2003).

Independent variables

Internal alignment $\left(X_{1}\right)$ is the set of commitments, policies, strategies, procedures, systems and behaviors that support the making of integrated customer decision which is based on suppliers' commercial and ethical commitment and resultant performance (Sisco and Wong 2008).

Perceived risks of serving key account $\left(X_{2}\right)$ means the risk of achieving and/or not achieving forecasted return or revenues and risk of unpredicted events in an ongoing business relationship that would result in unanticipated costs for the supplier (Woodburn et al. 2004).

Top management emphasis $\left(X_{3}\right)$ in key account management is conceptualized as the extent to which senior management participate in the key account management approach that develops the positive customer perception about the senior management commitment towards the key account management program (Homburg et al. 2002; Millman and Wilson 1999).

Team effort $\left(X_{4}\right)$ is the extent to which teams are formed to coordinate the necessary activities to serve the company's key account customers (Workman et al. 2003).

Supplier relational investment $\left(X_{5}\right)$ means the supplier's investment into the assets including non-transaction and transaction specific assets which marketers utilize to create a competitive advantage (Sharma 2006).

Perceived buyer relational investment $\left(X_{6}\right)$ means the buyer's investment into the assets which are idiosyncratic to the exchange and cannot be redeployed in other transactions and promote relational exchanges and enhance the commitment among the partners involved (Blau 1964; Cook and Emerson 1978; Pillai and Sharma 2003).

Relational intimacy $\left(X_{7}\right)$ means the feelings of affection and a sense of belongingness to the business relationship and indirectly development of a sense of belongingness towards the organization (Sin et al. 2006).

\section{THEORETICAL FRAMEWORK}

The study focuses on the use of an econometric approach for the assessment of technical efficiency followed by Battese and Coelli (1992) stochastic frontier model with a 
simple exponential specification of time-varying firm effects which incorporate for panel data associated with observations on a sample of $\mathrm{N}$ firms. The model is defined by:

$$
Y_{i}=f\left(x_{i} ; \beta\right) \exp \left(V_{i}-U_{i}\right) ; i=1,2, \ldots, N
$$

Where $Y_{\mathrm{i}}$ represent the logarithm of the production of the $i$-th firm; $X_{\mathrm{i}}$ represent the $(k X$ $1)$ vector of the logarithm of the input quantities of the $i$-th firm, $\beta$ is a vector of unknown parameters for the stochastic frontier. $V_{i}$ 's are random variables assumed to be iid. $N\left(0, \sigma_{\mathrm{v}}{ }^{2}\right)$, independently distributed of the $U_{i}$. $U_{i}$ 's are non-negative random variables which are assumed to account for technical inefficiency in production and are often assumed to be iid. $\mid N\left(0, \sigma_{\mathrm{u}}^{2}\right)$.

Technical efficiency of the i-th firm

$$
\mathrm{T} E_{i}=\exp \left(-U_{i}\right)
$$

In this study, the parameters of the stochastic frontier model (1) will be estimated using maximum likelihood estimation (MLE). Using the composed error terms of the stochastic frontier model (1), the total variation in output from the frontier level of output attributed to technical efficiency is defined by $\gamma=\sigma_{u}^{2} /\left(\sigma_{u+}^{2} \sigma_{v}^{2}\right)$ The variance parameter $\gamma$ lies on the interval $(0,1)$. In the truncated and half-normal distribution, the ratio of primary education specific variability to total variability, $\gamma$, is positive and significant, implying that primary education specific technical efficiency is important in explaining the total variability of output produced. This is done with the calculation of the maximum likelihood estimates for the parameters of the stochastic frontier model by using the computer program FRONTIER Version 4.1 (Coelli 1996).

The two general approaches are used to assess efficiency or performance of an entity, parametric methods like Stochastic Frontier Approach (SFA), Distribution-Free Approach and Thick Frontier Approach and non-parametric methods like Data Envelopment Analysis (DEA) and Free Disposal Hull which employ different techniques to envelop a data set with different assumptions for random noise and for the structure of the production technology. The performance or efficiency analysis in the industry with so many important development milestones is of high interest.

The reason why we used the stochastic frontier model rather than other as DEA does not have to be specified for the production function and it does not take into account random error hence the efficiency estimates may be bias if the production process is largely characterized by stochastic elements. The advantages of using the stochastic frontier Approach (SFA) that allows the effects of noise to be separated from the effects of inefficiency and generate good results only for single output and multiple inputs.

\subsection{High capacity oriented KAM performance Stochastic Frontier Model}

Followed by the original specification of (1), this model can be expressed in the following form:

$$
Y_{i}=\alpha+\beta_{1} X_{1}+\beta_{2} X_{2}+\beta_{3} X_{3}+\beta_{4} X_{4}+\beta_{5} X_{5}+\beta_{6} X_{6}+\beta_{7} X_{7}+\left(V_{i}-U_{i}\right) \quad i=1,2, \ldots, 33
$$


Where $Y_{i}$ represents the logarithm of the high capacity oriented key account management of the $i$-th firm;

$X_{1}$ represents the logarithm of the internal alignment quantities of the $i$-th firm;

$X_{2}$ represents the logarithm of the perceived risks quantities of the $i$-th firm;

$X_{3}$ represents the logarithm of the top management emphasis quantities of the $i$-th firm;

$X_{4}$ represents the logarithm of the team effort quantities of the $i$-th firm;

$X_{4}$ represents the logarithm of the supplier relational investment quantities of the $i$-th fi5m;

$X_{6}$ represents the logarithm of the perceived buyer relational investment quantities of the $i$-th firm;

$X_{7}$ represents the logarithm of the relational intimacy quantities of the -th firm;

$\beta_{1}, \beta_{2}, \beta_{3}, \beta_{4,} \beta_{5}, \beta_{6}, \beta_{7}$ are unknown parameters for the stochastic frontier to be estimated. The $V_{i}$. $U_{i}^{\prime}$ 's and 's are defined earlier in the theoretical framework of the model.

\subsection{Medium capacity oriented KAM performance Stochastic Frontier Model}

Followed by the original specification of (1), this model can be expressed in the following form:

$$
Y_{i}=\alpha+\beta_{1} X_{1}+\beta_{2} X_{2}+\beta_{3} X_{3}+\beta_{4} X_{4}+\beta_{5} X_{5}+\beta_{6} X_{6}+\beta_{7} X_{7}+\left(V_{i}-U_{i}\right) \quad i=1,2, \ldots, 35
$$

Where $Y_{i}$ represent the logarithm of the medium capacity oriented key account management of the $i$-th firm; $X_{i}^{\prime} s(i=1,2, \ldots, 7)$ are the logarithm of the input quantities of the $i$-th firm defined earlier; $\beta_{i}$ 's $(i=1,2, \ldots, 7)$ are unknown parameters to be estimated defined earlier.

\subsection{Low capacity oriented KAM performance Stochastic Frontier Model}

Followed by the original specification of (1), this model can be expressed in the following form:

$$
Y_{i}=\alpha+\beta_{1} X_{1}+\beta_{2} X_{2}+\beta_{3} X_{3}+\beta_{4} X_{4}+\beta_{5} X_{5}+\beta_{6} X_{6}+\beta_{7} X_{7}+\left(V_{i}-U_{i}\right) \quad i=1,2, \ldots, 44
$$

Where $Y_{i}$ represent the logarithm of the low capacity oriented key account management of the $i$-th firm; $X_{i}^{\prime} s(i=1,2, \ldots, 7)$ are the logarithm of the input quantities of the $i$-th firm and $\beta_{i}$ 's $(i=1,2, \ldots, 7)$ are unknown parameters to be estimated defined earlier.

\section{RESULTS AND DISCUSSION}

Table 1 presents the estimate of parameters using Ordinary Least Square (OLS) and Maximum Likelihood Estimation (MLE) methods. Log likelihood estimation for MLE method is greater than that of OLS method, that is, MLE is more appropriate to estimate parameters of the performance of high KA service companies. Supplier relational investment $\left(x_{5}\right)$ is significant in both estimation methods (OLS and MLE). Top management emphasis $\left(x_{3}\right)$ is significant in OLS method, however, this variable is insignificant in MLE method. 
Table 1

Estimate of parameters using Ordinary Least Square and Maximum Likelihood Estimation methods for KAM performance of Bangladeshi readymade garments companies with high KA serving capacity

\begin{tabular}{|c|c|c|c|c|c|}
\hline \multirow{2}{*}{ Variables } & \multirow{2}{*}{ Parameters } & \multicolumn{2}{|c|}{ OLS } & \multicolumn{2}{c|}{ MLE } \\
\cline { 3 - 6 } & & Coefficient & S.E & Coefficient & S.E \\
\hline Constant & $\beta 0$ & $0.22759 @$ & 0.25678 & $0.48318 @$ & 0.88665 \\
\hline$x_{1}$ & $\beta 1$ & $0.06887 @$ & 0.10665 & $0.08394 @$ & 0.25818 \\
\hline$x_{2}$ & $\beta 2$ & $-0.00987 @$ & 0.07270 & $-0.01907 @$ & 0.13051 \\
\hline$x_{3}$ & $\beta 3$ & $0.29311^{*}$ & 0.10911 & $0.11053 @$ & 0.29777 \\
\hline$x_{4}$ & $\beta 4$ & $-0.09401 @$ & 0.08009 & $-0.01936 @$ & 0.17779 \\
\hline$x_{5}$ & $\beta 5$ & $0.19327 *$ & 0.05796 & $0.00566^{*}$ & 0.08231 \\
\hline$x_{6}$ & $\beta 6$ & $0.01269 @$ & 0.04686 & $0.22924 @$ & 0.07669 \\
\hline$x_{7}$ & $\beta 7$ & $0.38731^{*}$ & 0.11698 & $0.35362 @$ & 0.27801 \\
\hline Sigma-squared & $\sigma^{2}$ & 0.00444 & & $0.00642^{*}$ & 0.00096 \\
\hline Gamma & $\gamma$ & & & $0.99996^{*}$ & 0.00088 \\
\hline mu & $\mu$ & & & $0.03802^{*}$ & 0.01597 \\
\hline log likelihood & & & & 50.16399 \\
\hline
\end{tabular}

*1\% level significant, ** 5\% level significant, *** 10\% level significant and @ insignificant. Source: Own elaboration.

Since the ratio of specific variability to total variability $(\boldsymbol{\gamma})$ is significant at $10 \%$ level of significance with positive value 0.99 , thus the efficiency is important in explaining the total variability of the output. The result is in the line with the previous researches and arguments of O'Regan and Ghobadian (2004) who find top management and line management involvement as organization's generic capability and explore them as very important drivers of overall performance. Again, Thoma (2007) explores that high-performance strategic account management programs proactively integrate top management into its internal program activities as well as external activities. On the other hand, development of relational capabilities through idiosyncratic investment is considered as an essential set of supplier's competencies that influence the success of a buyer-seller relationship (Newbert 2007). 
Table 2

Maximum-Likelihood estimates of Cobb-Douglas stochastic frontier model for KAM performance of Bangladeshi readymade garments companies with medium KA serving capacity

\begin{tabular}{|c|c|c|c|c|c|}
\hline \multirow{3}{*}{ Variables } & \multirow{3}{*}{$\begin{array}{c}\text { Parame- } \\
\text { ters }\end{array}$} & \multicolumn{4}{|c|}{ Model } \\
\hline & & \multicolumn{2}{|c|}{ OLS Estimates } & \multicolumn{2}{|c|}{ MLE Estimates } \\
\hline & & Coefficient & S.E & Coefficient & S.E \\
\hline Constant & $\beta 0$ & $0.92870 * * *$ & 0.34881 & $0.93172 * * *$ & 0.33355 \\
\hline$x_{1}$ & $\beta 1$ & 0.14782@ & 0.11905 & 0.14804@ & 0.10680 \\
\hline$x_{2}$ & $\beta 2$ & $-0.12508 * * *$ & 0.07592 & $-0.12512 * * *$ & 0.06893 \\
\hline$x_{3}$ & $\beta 3$ & 0.04779@ & 0.19256 & 0.04753@ & 0.17788 \\
\hline$x_{4}$ & $\beta 4$ & 0.04624@ & 0.18854 & 0.04699@ & 0.24335 \\
\hline$x_{5}$ & $\beta 5$ & $-0.22235 * * *$ & 0.09913 & $-0.22265 * * *$ & 0.09909 \\
\hline$x_{6}$ & $\beta 6$ & 0.05804@ & 0.09549 & 0.05798@ & 0.08595 \\
\hline$x_{7}$ & $\beta 7$ & $0.32410 * *$ & 0.21896 & $0.32348 *$ & 0.31756 \\
\hline Sigma-squared & $\sigma^{2}$ & 0.01040 & & $0.00808 * *$ & 0.00338 \\
\hline Gamma & $\gamma$ & & & 0.00616@ & 0.43551 \\
\hline $\mathrm{mu}$ & $\mu$ & & & -0.01411@ & 0.21951 \\
\hline log likelihood & & \multicolumn{2}{|c|}{34.78033} & \multicolumn{2}{|c|}{34.78021} \\
\hline
\end{tabular}

*1\% level significant, ** 5\% level significant, ***10\% level significant and @ insignificant. Source: Own elaboration.

Table 2 is to present the estimate of parameters using OLS and MLE methods. Log likelihood estimation for MLE method is same as for OLS method, that is, any estimation can be used to estimate parameters of the performance of medium KA service companies. Perceived risks of serving key account $\left(x_{2}\right)$, supplier relational investment $\left(x_{5}\right)$ and relational intimacy $\left(x_{7}\right)$ are significant in the both estimation method (OLS and MLE).

The result proves the hypothesized negative relationship between Perceived risks of serving key account and key account management performance study. Finding is in the line of the suggestion of Zupancic (2008) who opines that risk of serving the key customer has a strong connection to key account management and we do not know much about it. At the same time, literature confirm that KAM capability-related constructs, including relational investment and relational intimacy, can enhance firm performance in the exchange relationship (Buvik and John 2000; Kim, Cavusgil, and Calantone 2006). 
Table 3

Maximum-Likelihood estimates of Cobb-Douglas stochastic frontier model for KAM performance of Bangladeshi readymade garments companies with low KA serving capacity

\begin{tabular}{cccccc}
\hline \multirow{2}{*}{ Variables } & \multirow{2}{*}{ Parameters } & \multicolumn{2}{c}{ OLS Estimates } & \multicolumn{2}{c}{ MLE Estimates } \\
\cline { 3 - 6 } & & Coefficient & S.E & Coefficient & S.E \\
\hline Constant & $\beta 0$ & $1.01836^{* * *}$ & 0.18441 & $0.98563 * * *$ & 0.15143 \\
$x_{1}$ & $\beta 1$ & $0.12975 @$ & 0.08006 & $0.03453 @$ & 0.04265 \\
\hline$x_{2}$ & $\beta 2$ & $-0.11955 * *$ & 0.05968 & $-0.02603 @$ & 0.03770 \\
\hline$x_{3}$ & $\beta 3$ & $0.09243 @$ & 0.09104 & $0.15078^{* * *}$ & 0.04384 \\
\hline$x_{4}$ & $\beta 4$ & $0.03239 @$ & 0.05307 & $0.07184 * *$ & 0.03815 \\
\hline$x_{5}$ & $\beta 5$ & $0.03202 @$ & 0.05609 & $0.09316^{* * *}$ & 0.04810 \\
\hline$x_{6}$ & $\beta 6$ & $0.08304 @$ & 0.06377 & $0.04033 @$ & 0.04425 \\
\hline$x_{7}$ & $\beta 7$ & $0.02945 @$ & 0.09416 & $0.02173 @$ & 0.08071 \\
\hline Sigma-squared & $\sigma^{2}$ & 0.00628 & & $0.02109^{*}$ & 0.00422 \\
\hline Gamma & $\gamma$ & & & $0.999998^{* * *}$ & 0.00019 \\
\hline mu & $\mu$ & & $-0.108668 *$ & 0.02383 \\
\hline log likelihood function & & 53.52126 & 62.299144 \\
\hline
\end{tabular}

*1\% level significant, ** 5\% level significant, *** 10\% level significant and @ insignificant. Source: Own elaboration.

Table 3 presents the estimate of parameters of Low KA Serving Capacity using OLS and MLE methods. Log likelihood estimation for MLE method (62.299) is greater than that of OLS method (53.521), that is, MLE is more appropriate to estimate parameters of the performance of low KA service companies. From MLE estimation, top management emphasis $\left(x_{3}\right)$, team effort $\left(x_{4}\right)$ and supplier relational investment $\left(x_{5}\right)$ are significant for the low KA serving capacity performance of Bangladeshi readymade garments. Since the ratio of specific variability to total variability $(\boldsymbol{\gamma})$ is significant at $1 \%$ level of significance with positive value 0.99 , thus the efficiency is important in explaining the total variability of the output.

Study findings support the prior assumption and findings of Napolitano (1997), McDonald et al. (2003), Workman et al. (2003) and Ryals (2012) but contradict the finding of Koerner (2001) and Harro and Blinde (2005) who found that top management involvement generates negative outcomes when they involve without the prior knowledge of customer, 
competitive environment and such involvement is only for domination. For the team effort study finding is supporting the results of various past studies including Moon and Armstrong (1994) and Sengupta et al. (1997) but contradict with the study of Workman et al. (2003) that did not find a positive relationship between team use and KAM performance.

Table 4 presents the technical efficiency of the garments with High KA serving capacity. The average performance of the high KA serving capacity garments is 0.9207 . The lowest performing garment is showing efficiency level 0.7672 whereas highest efficiency level is 0.9985 . The better average performance of high KA serving capacity garments indicates these firms can develop their marketing capabilities through combining skills and knowledge along with the available resources (Vorhies and Morgan 2005).

Table 4

Garments Company's Technical Efficiency (TE) with high KA serving capacity

\begin{tabular}{|c|c|c|c|}
\hline Company Number & TE & Company Number & TE \\
\hline 1 & 0.9385 & 18 & 0.9344 \\
\hline 2 & 0.8886 & 19 & 0.9444 \\
\hline 3 & 0.9562 & 20 & 0.9506 \\
\hline 4 & 0.9054 & 21 & 0.7672 \\
\hline 5 & 0.9957 & 22 & 0.8757 \\
\hline 6 & 0.9985 & 23 & 0.9181 \\
\hline 7 & 0.8184 & 24 & 0.8886 \\
\hline 8 & 0.9411 & 25 & 0.9562 \\
\hline 9 & 0.9970 & 26 & 0.9133 \\
\hline 10 & 0.9409 & 27 & 0.9409 \\
\hline 11 & 0.9091 & 28 & 0.9948 \\
\hline 12 & 0.9666 & 29 & 0.8130 \\
\hline 13 & 0.9948 & 30 & 0.9092 \\
\hline 14 & 0.8130 & 31 & 0.8972 \\
\hline 15 & 0.9092 & 32 & 0.9444 \\
\hline 16 & 0.8972 & 33 & 0.9506 \\
\hline 17 & 0.9138 & & \\
\hline Mean Efficiency 0.9207 & & & \\
\hline
\end{tabular}

Source: Own elaboration.

Figure 1 is showing that most of the garments with high KA serving capacity are with above average performance. Among the thirty three high KA serving capacity garments, four garments' performances are almost one. That is, these four garments are very close to the perfect performance. 
Figure 1

Readymade garments company's Technical Efficiency with high KA serving capacity

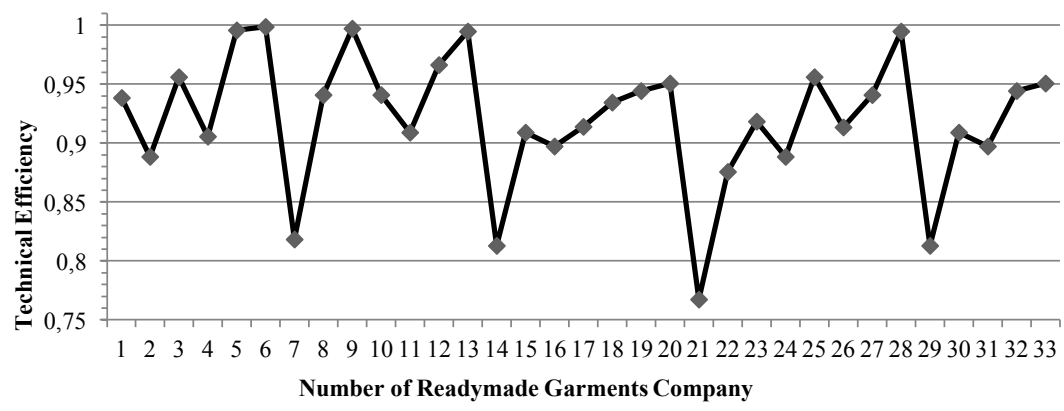

Source: Own elaboration.

Table 5 presents the technical efficiency of the garments with Medium KA serving capacity. The average performance of the medium KA serving capacity garments is 0.9973 . That is all the medium KA serving capacity garments have high performance which is very near to perfect efficiency. This may be because these suppliers are quite able to direct strategic capabilities toward primarily these customers and continues efforts to build specific capabilities so that they can meet the requirements of such customers better (Gounaris and Tzempelikos 2013).

Table 5

Garments Company's Technical Efficiency (TE) with medium KA serving capacity

\begin{tabular}{|c|c|c|c|}
\hline Company Number & TE & Company Number & TE \\
\hline 1 & 0.9972 & 19 & 0.9973 \\
\hline 2 & 0.9973 & 20 & 0.9974 \\
\hline 3 & 0.9974 & 21 & 0.9974 \\
\hline 4 & 0.9974 & 22 & 0.9973 \\
\hline 5 & 0.9973 & 23 & 0.9973 \\
\hline 6 & 0.9973 & 24 & 0.9973 \\
\hline 7 & 0.9973 & 25 & 0.9974 \\
\hline 8 & 0.9973 & 26 & 0.9973 \\
\hline 9 & 0.9973 & 27 & 0.9974 \\
\hline 10 & 0.9973 & 28 & 0.9975 \\
\hline 11 & 0.9973 & 29 & 0.9973 \\
\hline 12 & 0.9972 & 30 & 0.9973 \\
\hline 13 & 0.9973 & 31 & 0.9973 \\
\hline 14 & 0.9973 & 32 & 0.9973 \\
\hline 15 & 0.9973 & 33 & 0.9973 \\
\hline 16 & 0.9973 & 34 & 0.9973 \\
\hline
\end{tabular}




\begin{tabular}{|c|c|c|c|}
\hline 17 & 0.9974 & 35 & 0.9973 \\
\hline \multicolumn{3}{|c|}{18} \\
\hline \multicolumn{3}{|c|}{0.9972} \\
0.9973
\end{tabular}

Source: Own elaboration.

Figure 2 is showing the performance of the garments with medium KA serving capacity. The range of performance of the medium KA serving capacity is 0.9972 to 0.9975 with average 0.9973 that is, according to performance these garments are homogenous.

Figure 2

\section{Readymade garments company's Technical Efficiency with medium KA serving capacity}

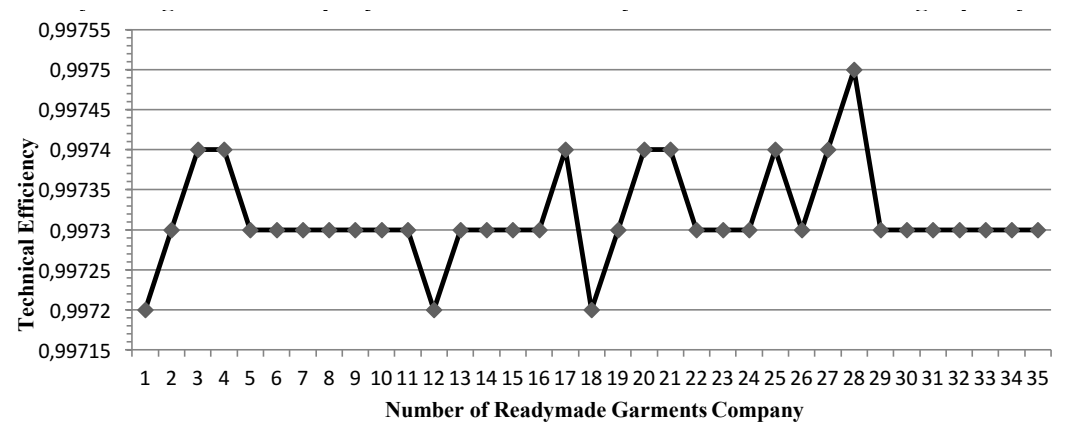

Source: Own elaboration.

Table 6 presents the technical efficiency of the garments with low KA serving capacity. The average performance of the low KA serving capacity garments is 0.9168 and range of the performance is 0.6995 to 0.9995 . Among three types KA serving capacity garments (high, medium and low), the average performance of the low KA serving capacity garments are less which is followed by high KA serving capacity supplier category. Less performance generates several insights as indicative in the existing literature. Smaller suppliers are often assumed to invest more into capability developments in their relationships with larger customers, but gain a lower return from this investment (Chen and Chen 2002) These suppliers face difficulties in effecting change, both within their own firms and in their relationships with larger customers (Holmlund and Kock 1996; Möller and Törrönen 2003). Additionally, small firms with fewer capabilities are compelled to develop their capabilities through relationships with other companies (Blomqvist 2002) that comes up in the form of investment in relational assets, utilizing their cross-functional people in the form of team efforts as well as involving their top management. 
Table 6

Garments Company's Technical Efficiency (TE) with low KA serving capacity

\begin{tabular}{|c|c|c|c|}
\hline Company Number & Technical Efficiency & Company Number & Technical Efficiency \\
\hline 1 & 0.9059 & 23 & 0.9315 \\
\hline 2 & 0.9893 & 24 & 0.9242 \\
\hline 3 & 0.9601 & 25 & 0.8570 \\
\hline 4 & 0.9302 & 26 & 0.9739 \\
\hline 5 & 0.9045 & 27 & 0.8902 \\
\hline 6 & 0.9651 & 28 & 0.9007 \\
\hline 7 & 0.9995 & 29 & 0.7897 \\
\hline 8 & 0.8730 & 30 & 0.8698 \\
\hline 9 & 0.9356 & 31 & 0.7304 \\
\hline 10 & 0.6995 & 32 & 0.8159 \\
\hline 11 & 0.9892 & 33 & 0.9402 \\
\hline 12 & 0.8427 & 34 & 0.9288 \\
\hline 13 & 0.9372 & 35 & 0.9405 \\
\hline 14 & 0.9789 & 36 & 0.8919 \\
\hline 15 & 0.9261 & 37 & 0.9485 \\
\hline 16 & 0.9850 & 38 & 0.9893 \\
\hline 17 & 0.9713 & 39 & 0.9045 \\
\hline 18 & 0.9770 & 40 & 0.9301 \\
\hline \multicolumn{3}{|c|}{$\begin{array}{c}19 \\
0.9908 \\
41\end{array}$} & 0.9770 \\
\hline 20 & 0.9476 & 42 & 0.9739 \\
\hline 21 & 0.8892 & 43 & 0.9007 \\
\hline \multirow[t]{2}{*}{22} & 0.8049 & 44 & 0.9288 \\
\hline & $\begin{array}{c}\text { Mean efficiency }= \\
0.9168\end{array}$ & & \\
\hline
\end{tabular}

Source: Own elaboration.

Figure 3 is showing the performance of the garments with low KA serving capacity. Among the forty four companies with low KA serving capacity, seven garments have performance which is near to one. The performances of low KA serving capacity garments have more volatility than medium and high KA serving capacity garments. This may be because smaller suppliers face difficulties in effecting change, both within their own firms and in their relationships with larger key customers (Holmlund and Kock 1996; Möller and Törrönen 2003). There may be a mistake in assessing and selecting the key accounts because evaluating the strategic attractiveness of different accounts and ensuring a balance between the resources supplier is possessing and its capabilities to serve the number of KAs in the long run, are important things for KAM success (Tzempelikos and Gounaris 2015). The result is also indicative to the lack of supplier capability which is an essential element to ensure before any initiative can be successful (Cannon and Perreault 1999). 
Figure 3

\section{Readymade Garments Company's Technical Efficiency with low KA serving capacity}

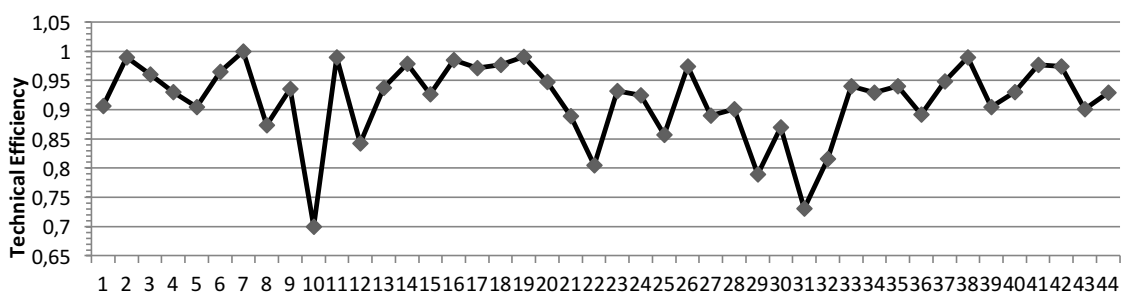

Number of Readymade Garments Companies

Source: Own elaboration.

\section{DISCUSSION AND IMPLICATIONS}

Irrespective of seven variables used in Stochastic Frontier model, the analysis shows that supplier relational investment, top management emphasis, relational intimacy, team effort and perceived risks of serving key account variables are significant in influencing the capacity oriented key account management performance. Among them, supplier relational investment variable found common in all three categories of high, medium and low capacity oriented supplier companies. On the other hand, internal alignment and perceived buyer relational investment are found insignificant for the key account management performance. The insignificant impact of internal alignment on KAM performance may be for the lack of line of visibility between the departments in the readymade garments industry in Bangladesh. Hence, interdepartmental connectedness is not considered as a separate aspect of their operation. This may be for top management holds the total authority and oversee the whole aspects of their operations that make the internal alignment less vital. On the other hand, insignificant result for perceived buyer relational investment indicates that there may be the availability of relational asymmetry where world renowned key retail buyers like Wal-Mart, Levi Strauss, Zara, Tesco, Gap, Carrefour, Marks and Spencer, H\&M and Tommy Hilfiger (Rahman 2010) are more influencing than their supplier counterparts. Consequently, these key retailers fell fewer obligations to invest in relational assets.

\subsection{Theoretical implications}

One contribution of this study is the assembling of multiple variables acting as drivers for key account management performance using Stochastic Frontier Analysis. A second contribution of the study is to identify several variables that are most important and lead to KAM performance.

In terms of the variables found significant in the study, supplier relational investment is the most important variable that to lead higher KAM performance. It indicates that to manage and sustain better performance with the key account supplier has to invest more 
in relational assets. The supplier relational investment creates a distinctive capability that enables the supplier to respond to the individual key account requirements properly. On the other hand, this type of relational investment ensures durable competitive advantages as it is idiosyncratic in nature.

The most common second variable found significant in the study is top management emphasis in key account management program. In the key account programs, top management emphasis generates tripartite benefits for both key accounts and supplier. First, such emphasis and involvement provide a signal to the internal concerned that better performance is expected from them to make the program successful. On the other hand, key account realizes that it is being treated as key and supplier is committed to serving its requirements best. Finally, empowering the key account team through necessary resources is facilitated by the top management involvement with the key account management program.

The significant association between perceived risks in serving key account and key account management performance indicates that when garments companies feel a high degree of perceived risks in serving their key customers, the performance of key account management program may suffer. In the key account relationship, the organizational capability to operate well through high performance in account management has become a significant issue. In this connection, associated risks in the exchange relationship making the performance level vulnerable. Accordingly, developing the relational safeguard through investment is important to perpetuate the key account relationship. The significant relationship of relational investment with key account management performance in all three supplier categories supports this notion.

The study found that relational intimacy significantly impacts on key account management performance. This result indicates that for a successful KAM program appropriate intertwining between supplier and key account make them better acquaint on each other. Accordingly, relational intimacy brings buyers and sellers together on a common cause or emotion and sustains the key account relationship.

\subsection{Managerial implications}

A number of important managerial implications can be forwarded from this research. First, development of the multidimensional stochastic key account management model provides managers with a structured way to see at their key account management program. Especially, they can proceed with the following considerations that will facilitate their decision making.

- Extend of doing with different influencing variables for serving their key accounts,

- Company's extent of investment in relational assets in the key account program,

- Level of their top management emphasis on the key account management program,

- An evaluation of the level of relational intimacy;

- $\quad$ Extend of the team effort as well as a proper perception of risks associated with serving the key accounts. 
Second, the Stochastic Frontier Analysis results provide managers with guidance concerning various factors having the prime effects on capacity oriented key account management performance. Supplier investments in relational assets as well as top management emphasis on KAM program are particularly important. In the key account relationship, relational investments increase the supplier capacity to serve the key accounts effectively. On the other hand, top management emphasis facilitates the quick access to the organizational resources and assets to invest in the key accounts. Their involvement also shows the supplier company commitment to the key account relationship.

Third, relational intimacy has a significant effect on KAM performance. Through the relational intimacy, supplier could be able to know key customers better, interact more on their mutual interests and effectuate better performance.

Fourth, a team effort should be incorporated to serve the key accounts.

Finally, the supplier should exercise caution, as risks are associated with the key account management. The result shows a negative but significant impact of perceived risks of serving key account on key account management performance.

\subsection{Limitations and future research direction}

There are a number of limitations that open up the horizons for future interesting research in this field. First and foremost is the study's single industry focus and cross-sectional design which has all the limitation of such a design. To avoid the potential industry specificity, future studies should explore how various industry specificity drive the key account management performance.

Second, our study focuses on the direct effect of various factors on key account management performance. There may be an interacting variable that may interact with these variables and KAM performance. Future research should consider the moderators between the variables and key account management performance.

It is most common that market turbulence and competitive intensity have an impact on performance. An industry like readymade garments with higher intensity of competition from the international supplier as well as market turbulence is affected more in showing its performance in key account management. This should be kept in mind when evaluating the results, and further research is required.

Performance may vary with the passes of time and experience gather from the key account relationship. It is usual that supplier came to know their key accounts better in the long-rum. Therefore, more positive performance could arise later for the KAM program. To examine this issue, it might be interesting and worthwhile to conduct studies with a wider time horizon.

\section{CONCLUSION}

This study dealt with the Stochastic Frontier Model to evaluate the capacity oriented key account management performance using primary data collected from 112 readymade garments companies in Bangladesh. Both Method of Likelihood Estimation (MLE) and 
Ordinary Least Square (OLS) estimations were used to estimate the parameters of capacity oriented key account management performance of garments companies. The Method of Likelihood Estimation (MLE) found more appropriate to estimate parameters of the performance of companies with high and low KA Service capacity but the exception of the companies with medium KA service capacity where MLE and OLS show similar results. In case of MLE estimation, supplier relational investment $\left(x_{5}\right)$ is recorded significant for the performance of garments companies with high, medium and low KA serving capacity in Bangladesh. Efficiency is found as an important aspect in explaining the total variability of the output for both companies with high and low KA service capacity as the ratio of specific variability to total variability $(\boldsymbol{\gamma})$ is significant at $1 \%$ level of significance with a positive value of 0.99 . The average performance of garments companies with low KA serving capacity is observed less, which is followed by high KA serving capacity among three types (high, medium and low). The performance of garments companies with low serving capacity is found more volatile than companies with medium and high key account serving capacity.

This paper makes its contribution to scholarship on three broad fronts. First, we extend the key account management literature to include seven influencing variables of key account management performance. We do so by dividing the variables into three categories namely operational variables, organizational variables and relational variables that are consistent with and complementary to the thinking in this research stream, facilitating seamless integration across the analytic activities and contributing to a more comprehensive key account management performance model. Second, we focus on a business-to-business relationship from the context of developing country suppliers and their international key customer counterparts and develop the theory through showing how to do these three types of variables impact on the capacity oriented key account management performance. Third, we introduce the three levels of capacity concerning to the garments companies ability to serve key account customers and show how does performance vary in key account management with regards to the companies with high, medium or low capacity.

This study's contributions are not limited, however, to the field of academia. As key account management can be a significant basis for developing a competitive advantage (Gounaris and Tzempelikos 2014), present study model on key account management and subsequent empirical results have strong implications for managers and for strategists. This paper provides a set of tools for scanning the important influencing variables that can help managers to visualize their impact on their capacity that is fundamental for showing greater performance in the field of key account management.

Not all organization's capacities are worthwhile unless the utilization of such capacities can generate incremental performance. This is because capacity enhances the supplier performance in their key account management (Sinkovics et al.2015).

The motivation to conduct this study is to have a better understanding on the influence of several operational, organizational and relational factors on capacity oriented key account management performance in the context of readymade garments industry in Bangladesh using Stochastic Frontier model.

From the practitioner points of view, the significant influence of supplier relational investment, top management emphasis, relational intimacy, team effort and perceived risks of serving key account variables on firm's capacity to show better performance inevitably 
provides diversified insight into the management operations in garments industry. These insights may help them to prioritize the investment for a key account, develop strong bonds with the key account through top management patronization and team efforts as well as alert them in considering the customer value as risks are involved in key account management. Accordingly, from such insights managers will be more vigilant in appropriating valuable resources necessary for capacity build up and resulting performance in key account management. In both MLE and OLS estimation, as these variables show different significance in connection to the capacity of the organizations, respective organizations with their high, medium or low key account serving capacity get clear guidelines on which factors they should give more emphasize than others.

\section{ACKNOWLEDGEMENTS}

The authors thank two anonymous reviewers for their valuable comments on this article. We acknowledge and thank Professor Belén Vallejo Alonso editor and director of Cuadernos de Gestión for all of her generous supports.

\section{REFERENCES}

Abratt, R., and Kelly, P. M., 2002. Customer-supplier partnerships: perceptions of a successful key account management program. Industrial Marketing Management, 31(5), 467-476.

Ahmmed, K., and Noor, N. A. M., 2012. Key account management: Towards a multidimensional definition. East Asian Journal of Business Management, 2(1), 5-13.

Atanasova, Y., and Senn, C., 2011. Global customer team design: Dimensions, determinants, and performance outcomes. Industrial Marketing Management, 40(2), 278-289.

Bangladesh Garment Manufacturers and Exporters Association (BGMEA), 2010. Member List. Available from http://www.bgmea.com.bd/member/memberlist. [Accessed 5 August 2010].

Bangladesh Garment Manufacturers and Exporters Association (BGMEA), 2016. Member List. Available from http://www.bgmea.com.bd/member/memberlist [Accessed 20 November 2016].

Bangladesh Garment Manufacturers and Exporters Association (BGMEA), 2016. Trade Information. Available from http://bgmea.com.bd/home/pages/TradeInformation [Accessed 20 November 2016].

Barrett, J., 1986. Why major account selling works. Industrial Marketing Management, 15(1), 63-73.

Battese, G.E. and Coelli, T. J., 1992. Frontier production functions, technical efficiency and panel data: with application to paddy farmers in India. Journal of Productivity Analysis, 3(1-2), 153-169.

Black, K., 2010. Business Statistics for Contemporary Decision Making. 6th ed. USA: John Wiley \& Sons. 
Blau, P. M., 1964. Exchange and power in social life. USA: Transaction Publishers.

Blomqvist, K., 2002. Partnering in the dynamic environment: The role of trust in asymmetric technology partnership formation. Thesis, (PhD). Lappeenranta University of Technology.

Boles, J., Johnston, W., and Gardner, A., 1999. The selection and organization of national accounts: a North American perspective. Journal of Business \& Industrial Marketing, 14(4), 264-282.

Breed, A. G., 2012. Why Asian Garment Factories Remain Dangerous. The Irrawaddy Magazine. Available from http://www.irrawaddy.org/archives/21108. [Accessed 15 December 2012].

Buvik, A., and John, G., 2000. When does vertical coordination improve industrial purchasing relationships? Journal of Marketing, 64(4), 52-64.

Cannon, J. P., and Perreault Jr, W. D., 1999. Buyer-seller relationships in business markets. Journal of Marketing Research, 36(4), 439-460.

Chen, H., and Chen, T. -J. 2002. Asymmetric strategic alliances: A network view. Journal of Business Research, 55(12), 1007-1013.

Coelli, T. J., 1996. A guide to FRONTIER version 4.1: a computer program for stochastic frontier production and cost function estimation, 96(07). pp. 1-32. CEPA working paper.

Cook, K. S., and Emerson, R. M., 1978. Power, equity and commitment in exchange networks. American Sociological Review, 43(5), 721-739.

Cooper, D. R., and Schindler, P. S., 2006. Marketing Research. New York: McGraw-Hill.

Day, G. S., (1994). The capabilities of market-driven organizations. The Journal of Marketing, 58(4), 37-52.

Ford, D., Håkansson, H., and Johanson, J., 1986. How do companies interact? Industrial Marketing \& Purchasing, 1(1), 26-40.

Ganesan, S., 1994. Determinants of long-term orientation in buyer-seller relationships. The Journal of Marketing, 58(2), 1-19.

Gounaris, S., and Tzempelikos, N., 2013. Key account management orientation and its implications: A conceptual and empirical examination. Journal of Business-to-Business Marketing, 20(1), 33-50.

Gounaris, S. and Tzempelikos, N., 2014. Relational key account management: Building key account management effectiveness through structural reformations and relationship management skills. Industrial Marketing Management, 43(7), 1110-1123.

Guesalaga, R., and Johnston, W., 2010. What's next in key account management research? Building the bridge between the academic literature and the practitioners' priorities. Industrial Marketing Management, 39(7), 1063-1068.

Haider, M. Z., 2007. Competitiveness of the Bangladesh ready-made garment industry in major international markets. Asia-Pacific Trade and Investment Review, 3(1), 3-27.

Haque, S. A., 2010. The Road to Recovery. Forum, 3(9). Available from http://www.thedailystar.net/forum/2010/October/road.htm [Accessed 10 October 2010].

Harro, T., and Blinde, J., 2005. The executive dilemma: Part II-How to conduct an executive-to-executive call that drives value and results for all. Velocity, 7(2), 23-27.

Henderson, R., and Cockburn, I., 1994. Measuring competence? Exploring firm effects in pharmaceutical research. Strategic management journal, 15, 63-63. 
Holmlund, M., and Kock, S., 1996. Buyer dominated relationships in a supply chain - A case study of four small-sized suppliers. International Small Business Journal, 33(1), 26-41.

Homburg, C., Giering, A., and Menon, A., 2003. Relationship Characteristics as Moderators of the Satisfaction-Loyalty Link: Findings in a Business-to-Business Context. Journal of Business-to-Business Marketing, 10(3), 35-62.

Homburg, C., Workman, J. P., and Jensen, O., 2002. A configurational perspective on key account management. The Journal of Marketing, 66(2), 38-60.

Huq, A., 2006 February, 4. Success one stitch at a time. The daily Star. Available from http://www.thedailystar.net/suppliments/2006/15thanniv/celebrating_bd/celeb_bd10. htm [Accessed 10 October 2010].

Jaworski, B. J., and Kohli, A. K., 1993. Market orientation: antecedents and consequences. The Journal of Marketing, 57(3), 53-70.

Kempeners, M. A., and van der Hart, H. W., 1999. Designing account management organizations. Journal of Business \& Industrial Marketing, 14(4), 310-335.

Kim, D., Cavusgil, S. T., and Calantone, R. J., 2006. Information system innovations and supply chain management: channel relationships and firm performance. Journal of the Academy of Marketing Science, 34(1), 40-54.

Koerner, L. V., 2001. The role of senior executive team in major accounts. Velocity, 3, 27-29.

Krejcie, R. and Morgan, D., 1970. Determining sample size for research activities. Educational and Psychological Measurement, 30, 607-610.

Lovelock, C. H., 1992. Seeking synergy in service operations: Seven things marketers need to know about service operations, European Management Journal, 10(1), 22-29.

McDonald, M., Rogers, B., and Woodburn, D., 2003. Key customers- How to manage them profitably. UK: Butterworth Heinemann.

McGrath, R. G., MacMillan, I. C., and Venkataraman, S., 1995. Defining and developing competence: A strategic process paradigm. Strategic Management Journal, 16(4), 251275.

Millman, T., and Wilson, K., 1999. Processual issues in key account management: underpinning the customer-facing organisation. Journal of Business \& Industrial Marketing, 14(4), 328-344.

Möller, K., and Törrönen, P., 2003. Business suppliers’ value creation potential. A capability-based analysis. Industrial Marketing Management, 32(2), 109-118.

Moon, M. A., and Armstrong, G. M., 1994. Selling teams: A conceptual framework and research agenda. Journal of Personal Selling \& Sales Management, 14(1), 17-30.

Napolitano, L., 1997. Customer-supplier partnering: a strategy whose time has come. Journal of Personal Selling \& Sales Management, 17(4), 1-8.

Newbert, S. L., 2007. Empirical research on the resource $\square$ based view of the firm: an assessment and suggestions for future research. Strategic Management Journal, 28(2), 121-146.

Nuruzzaman and Haque, A., 2009. Lead Time Management in the Garment Sector of Bangladesh: An Avenue for Survival and Growth. European Journal of Scientific Research, 33(4), 617-629. 
Ojasalo, J., 2001. Key account management at company and individual levels in business-to-business relationships. Journal of Business \& Industrial Marketing, 16(3), 199220.

O'Regan, N., and Ghobadian, A., 2004. The importance of capabilities for strategic direction and performance. Management Decision, 42(2), 292-313.

Pardo, C., 1999. Key account management in the business-to-business field: a French overview. Journal of Business \& Industrial Marketing, 14(4), 276-297.

Perry, M. L., Pearce, C. L., and Sims Jr, H. P., 1999. Empowered selling teams: How shared leadership can contribute to selling team outcomes. Journal of Personal Selling \& Sales Management, 19(3), 35-51.

Pillai, K. G. and Sharma, A., 2003. Mature relationships: why does relational orientation turn into transaction orientation? Industrial Marketing Management, 32(8), 643- 651.

Rahman, M. M., 2010. Living wage is not just wages. Forum, 3(9). Available from http:// www.thedailystar.net/forum/2010/October/living.htm [Accessed 1 October 2012].

Rahman, N. and Mirdha, R.U., 2009. The Garments of Recession. Star Weekend Magazine, 8(64). Available from http://www.thedailystar.net/magazine/2009/04/02/cover. htm [Accessed 4 April 2012].

Ruiz-Ortega, M. J., and García-Villaverde, P. M., 2008. Capabilities and competitive tactics influences on performance: Implications of the moment of entry. Journal of Business Research, 61(4), 332-345.

Ryals, L., 2012. How to succeed at key account management. Harvard Business Review, July 13.

Salojarvi, H., Sainio, L. M., and Tarkiainen, A. 2010. Organizational factors enhancing customer knowledge utilization in the management of key account relationships. Industrial Marketing Management, 39(8), 1395-1402.

Sengupta, S., Krapfel, R. E., and Pusateri, M. A., 1997. Switching costs in key account relationships. Journal of Personal Selling \& Sales Management, 17(4), 9-16.

Sharma, A., 2006. Success factors in key accounts. The Journal of Business and Industrial Marketing, 21(3), 141-150.

Sherman, S., Sperry, J., Reese, S., and Reese, S. J., 2003. The seven keys to managing strategic accounts. New York: McGraw-Hill Inc.

Shi, L. H., White, J. C., Zou, S. and Cavusgil, S. T., 2010. Global account management strategies: drivers and outcomes. Journal of International Business Studies, 41(4) 620638.

Sinkovics, R.R., Kim, D. and Lew, Y.K., 2015. Drivers and performance implications of international key account management capability. International Business Review, 24(4), 543-555.

Sin, L. Y. M., Tse, A. C. B., Yau, O. H. M., Lee, J. S. Y., and Chow, R. P. M., 2002. The effect of relationship marketing orientation on business performance in a service-oriented economy. Journal of Services Marketing, 16(7), 656-676.

Sin, L. Y. M., Tse, A. C. B., Chan, H., Heung, V., and Yim, F. H. K., 2006. The effects of relationship marketing orientation on business performance in the hotel industry. Journal of Hospitality \& Tourism Research, 30(4), 407.

Sisco, C. and Wong, J., 2008. Internal alignment: an essential step to establishing sustainable supply chains- a beyond monitoring trends report (Business for Social Responsi- 
bility, October). Available from http://www.bsr.org/reports/BSR_Internal_Alignment_ Trends_Report.pdf [Accessed 28 October 2012]

Spencer, R., 1999. Key accounts: effectively managing strategic complexity. Journal of Business \& Industrial Marketing, 14(4), 291-310.

Thoma, A., 2007. Critical change capabilities for sustaining high-performance SAM programs: results from a global survey. Velocity, 3, 27-30.

Tsai, Y. S. and Chen, J. Y., 2008. The dimensions of key account management in Taiwan it industry: viewpoints of supplier and its key account. Paper presented at the Oxford Business \&Economics Conference Program (pp. 1-17). UK: Oxford.

Tzempelikos, N., and Gounaris, S., 2015. Linking key account management practices to performance outcomes. Industrial Marketing Management, 45, 22-34.

Vorhies, D. W. and Morgan, N. A., 2005. Benchmarking marketing capabilities for sustained competitive advantage. Journal of Marketing, 69(1), 80-94.

Wengler, S., Ehret, M., and Saab, S., 2006. Implementation of key account management: who, why, and how? An exploratory study on the current implementation of key account management programs. Industrial Marketing Management, 35(1), 103-112.

Woodburn, D., Holt, S. and McDonald, M., 2004. Key customer profitability: Making money in strategic customer partnerships. The Cranfield Key Account Management Best Practice Club, Cranfield.

Workman, J. P., Homburg, C., and Jensen, O., 2003. Intraorganizational determinants of key account management effectiveness. Journal of the Academy of Marketing Science, 31(1), 3-21.

Wuyts, S., and Geyskens, I., 2005. The formation of buyer-supplier relationships: detailed contract drafting and close partner selection. Journal of Marketing, 69(4), 103-117.

Zupancic, D., 2008. Towards an integrated framework of key account management. Journal of Business \& Industrial Marketing, 23(5), 323-331.

Zupancic, D. and Müllner, M., 2008. International Key Account Management in Manufacturing Companies: An Exploratory Approach of Situative Differentiation. Journal of Business-to-Business Marketing, 15(4), 455-75. 